\title{
EQUITY AND INNOVATION: USING TRADITIONAL ISLAMIC BANKING MODELS TO REINVIGORATE MICROLENDING IN URBAN AMERICA
}

\author{
Jay Lee
}

\begin{abstract}
"Anticipate charity by preventing poverty; assist the reduced fellowman, either by a considerable gift, or a sum of money, or by teaching him a trade, or by putting him in the way of business, so that he may earn an honest livelihood, and not be forced to the dreadful alternative of holding out his hand for charity. This is the highest step and the summit of charity's golden ladder."
\end{abstract}

--Maimonides [Moses ben Maimon], 1135-1204. ${ }^{1}$

\section{INTRODUCTION}

The United Nations declared 2005 the International Year of Microcredit. ${ }^{2}$ Arising in the Third World in the early 1970 s, microcredit ${ }^{3}$ developed as a means to provide extremely poor people, especially women, with access to credit and an alternative to charity. ${ }^{4}$ Commenting on the significance of the resolution, Mark Malloch Brown, Administrator of the U.N. Development

\footnotetext{
* J.D. Candidate, 2006, Indiana University School of Law, Indianapolis, Indiana; BA Germanic Studies, Slavic Languages \& Literatures, Russian/Eastern European Institute Area Certificate, 1996, Indiana University, Bloomington, Indiana.

1. JohN BARTLETT, FAMILIAR QUOTATIONS 122 (Justin Kaplan ed., 16th ed. 1992); see SUSAN R. JONES, LEGAL GUIDE TO MICROENTERPRISE DEVELOPMENT 65-66 (2004). "[A]ccording to Maimonides, a Jewish sage, the greatest level of tzedekah 'is to strengthen the hand of the poor by means of gift or loan or by going into partnership with him so that he can become selfsufficient." Id. (quoting Faith Based Microenterprise, Part II: How is Faith-Based Microenterprise Different?, 9 AEO EXCHANGE, Jan.-Mar. 2003, at 1, available at http://www.microenterpriseworks.org/newsletter/Jan-Mar2003/Jan.Mar2003web.pdf).

2. General Assembly Greenlights Programme for the International Year of Microcredit 2005: Observance Will Promote Access to Financial Services and Empowerment of Poor. Especially Women, M2 PRESSWIRE, Dec. 31, 2003 [hereinafter Greenlights].

3. The terms microcredit, microfinance, and microlending are used interchangeably throughout the literature. Microcredit and microlending are more commonly used internationally, where proponents stress the extension of credit as a means to empower the extremely poor whereas American sources are more likely to stress the entrepreneurial aspects of credit extension with such terms as microfinance, microbusiness, or microentrepreneurship.

4. See Microcredit's Limits, INT'L HERALD TRIBUNE, May 26, 2004, at 8 [hereinafter, Microcredit's Limits]; see also Microcredit Could Lift Millions Out of Poverty, DEUTSCHE PRESSE-AGEnTUR, Sept. 8, 1995 [hereinafter, Millions out of Poverty].
} 
Program, noted that sustainable access to microfinance is a central strategy in the United Nations' goal to "halv[e] extreme poverty and hunger by 2015.",5 According to Secretary General Kofi Annan, such access "helps alleviate poverty by generating income, creating jobs, allowing children to go to school, enabling families to obtain health care, and empowering people to make the choices that best serve their needs." ${ }^{\text {B }}$ By the end of 2001, the number of people in extreme poverty who benefited from microcredit programs rose to 26.8 million. ${ }^{7}$ This marks a fourfold expansion in microcredit since $1997 .^{8}$ The goal for 2005 is to have helped 100 million poor people start their own business. ${ }^{9}$ This number encompasses about one-fifth of the world's population living in poverty. ${ }^{10}$ The thirty-four largest microlending programs serve a total of 7.5 million people, of whom seventy-seven percent are female." Thus, microcredit also serves as a means to combat the "feminization of poverty." the founder of Women's World Banking, a non-profit lending institution that has expanded into fifty nations in Africa, Asia, Latin, and North America since its founding in $1979,{ }^{13}$ stresses the importance of female involvement: "Credit for women is our right and we must fight for it."14

This Note explores applications of microcredit in the United States and suggests an approach to extend the benefits of such programs to a wider clientele by means of a program that is both novel and traditional: equity lending based on Islamic banking models. By effectively sharing the profits of fledgling businesses, microlenders who adopt an equity lending model can lower interest rates without substantially increasing lender risk, offer their services to more microentrepreneurs, and support their infrastructure through an influx of capital from their clients. This final benefit, in turn, allows the microentrepreneur to give back to the group of people who had the faith in her to make the original loan. ${ }^{15}$

This Note comprises three parts that analyze microcredit and its current application in the United States, and it suggests a method of interest reduction

5. Greenlights, supra note 2 , at 1 .

6. Id.

7. UN Under-Secretary General Lauds Effectiveness of Microcredit as Second Committee Takes Up Implementation of Decade for Eradication of Poverty; Millions, Particularly Women, Lifted Out of Extreme Poverty, Delegates Told, M2 PRESSWIRE, Oct. 10, 2003.

8. Greenlights, supra note 2 , at 1 . $15,1999$.

9. Gordon Platt, Changes Urged in Microcredit Lending, Journal of Commerce, Sept.

10. Millions Out of Poverty, supra note 4, at 1.

11. Platt, supra note 9, at 9.

12. UN Second Committee Panel Discussion Hears Experts Underline Important Role of Microcredit in Raising Housing Incomes, Boosting Living Standards, M2 PRESSWIRE, Oct. 24,2003 ; see also, Platt, supra note 9, at 9 (noting that 1 billion of the 1.5 billion people living worldwide on less than $\$ 1$ per day are women).

13. Millions Out of Poverty, supra note 4, at 1.

14. Id.

15. See JONES, supra note 1 , at 41 . 
that could enable U.S. microlenders to serve a greater number of poor microentrepreneurs. Part I provides a general introduction to microcredit and the evolution of the Grameen Model, pioneered by the Bangladeshi economist Muhammad Yunus. Part II explores microlending in the United States and the niche microlending provides in the broader realm of fringe lending. This section also describes various governmental and non-profit applications that target specific groups, such as refugees, mothers receiving assistance, and the disabled. An important component of this section is the welfare transition from Aid to Families with Dependent Children (AFDC) to Temporary Assistance for Needy Families (TANF) and its effect on microcredit programs.

Part III examines equity lending under traditional Islamic banking practices and how such lending might be applied in an urban context in the United States. Several caveats are raised by such an approach. First, such practice would complicate the lender-borrower relationship, increasing the cost per loan in terms of work hours and decreasing the borrower-to-lender ratio. ${ }^{16}$ In other words, despite lower interest rates attracting more clients, the general quality of service might be compromised. Second, the Islamic provenance of equity lending might inhibit its application in a society currently beset with anti-Muslim sentiment. ${ }^{17}$ Finally, proponents of microcredit stress that it is not a panacea. People who only lack seed money but who have the requisite skill, stamina, and luck can create a successful business. As a result, those who cannot participate in such programs may be further stigmatized.

Despite these concerns, equity lending in a microcredit context bears closer scrutiny. Although such an approach may initially seem exotic, in many ways such ideas are extensions of practices already in place in U.S. microcredit programs. Also, while equity lending might be impractical on a larger scale, microlenders typically have closer relationships with their clientele and offer far more services and support than traditional financial institutions. In such an environment, equity lending is a natural addition to the family. Additionally, it can serve as a means to foster skills and relationships within communities that have been traditionally shut out from other avenues of economic development. ${ }^{18}$

16. Anthony D. Taibi, Banking, Finance, and Community Economic Empowerment: Structural Economic Theory, Procedural Civil Rights, and Substantive Racial Justice, 107 HARV. L. REV. 1465, 1527 (1994).

17. See, e.g., Slayings Spark New Wave of Anti-Muslim Sentiment, AUGUSTA CHRON., Jan. 23, 2005, at A9; Jack Encarnacao, Officials Say Arson Was Cause of Fire in Springfield Mosque, Boston GloBE, Dec. 12, 2005, at B1; Shaik Ubaid, American Muslims Hope for the Best: Despite Promises by President Bush, this Community's Fears of a Backlash Are as Strong as Ever, NEWSDAY, Dec. 7, 2004, at A43.

18. See, e.g., MuHAMMAD YunUs, BanKeR TO THE POOR: Microlending AND THE BATtLE AGAINST WORLD POVERTY 180-88 (1999) (describing microcredit initiatives among the Lakota Sioux as well as centers of rural and urban poverty). 


\section{MICROCREDIT AND THE EVOLUTION OF THE GRAMEEN MODEL.}

The idea of microcredit arose in the Third World as a formalized version of traditional methods of credit extension. ${ }^{19}$ There are three overarching points to remember regarding microcredit: it is not new, it is not simply about money, and it is not enough. ${ }^{20}$ In many circles, at least in the mid-to late-1990s, it was haled as a panacea to cure world poverty. ${ }^{21}$ While it is a useful tool for combating poverty, both abroad and at home, microcredit has its limitations. ${ }^{22}$ Small loans are a means by which people can bring themselves out of poverty, but such loans can only benefit those who are in a position to use them productively. ${ }^{23}$ Thus, microcredit is not a means to assist the estimated 40.3 million people living with HIV/AIDS ${ }^{24}$ or the world's 35.5 million refugees and displaced persons. ${ }^{25}$ Moreover, some donor states might confuse the promise of microcredit with the need for aid, ${ }^{26}$ thereby preventing organizations from serving those who might benefit most effectively. ${ }^{27}$

Another important aspect of microcredit is the empowerment of women it engenders. ${ }^{28}$ Ninety-four percent of the Grameen Bank's clients in Bangladesh are women. ${ }^{29}$ By fostering this participation, microcredit allows women to develop financial autonomy, thereby promoting gender-equity and improving

19. Microfinance-Credit Lending Models, at http://www.grameeninfo.org/mcredit/cmodel.html (last modified Aug. 1, 2000) [hereinafter Lending Models].

20. The Virtual Library on Microcredit: Documents and Reports, available at http://www.gdrc.org/icm/icm-documents.html (n.d.) (last visited Mar. 19, 2006).

21. See generally Kathy McKenna, Little Loans Mean a Lot, N.Y. TiMES, June 3, 1987, at A26 (letter to the editor from an activist in the fight against world hunger in which the activist points to low default rates as proof that the poor are "bankable.").

22. See Microcredit's Limits, supra note 4, at 1. The United States and other donor nations should not "use this program as a substitute for other more basic ways of helping the poorest of the poor." Id.

23. Microcredit Alone Won't Reduce Poverty: WB Study, THE INDEPENDENT, Jan. 15, 1999, available at LEXIS, News Library, Emerging Markets Datafile.

24. World HIV and AIDS Statistics, available at http://www.avert.org/worldstats.htm (last updated Feb. 9, 2006).

25. Key Statistics, World Refugee Survey, 2004, Table 1, at http://www.refugees.org/data/wrs/04/pdf/key_statistics.pdf (last visited Mar. 19, 2006).

26. Microcredit's Limits, supra note 4, at 1.

Starting next year, half of U.S. support for microfinance groups must go to those living well below their nations' poverty lines, or earning less than $\$ 1$ a day.... [T] he program could well force loans on people who may not be ready for them or who may really need outright aid instead.

ld.

27. See id.

28. See Millions Out of Poverty, supra note 4; see generally Jude L. Fernando, The Role of NGOs: Charity and Empowerment: Nongovernmental Organizations, Micro-Credit, and Empowerment of Women, 554 ANNALS AM. ACAD. POL. \& SoC. SCI. 150 (1997).

29. Basic

Facts

About

Microfinance, 
household and community stability. ${ }^{30}$ Ironically, these successes are due, in part, to institutions like larger sponsor banks and corporations, which are not usually positively associated with social justice issues. ${ }^{31}$ In fact, these institutions are considered to be "obstacles to women's empowerment."32

\section{A. The Grameen Model}

The Grameen ${ }^{33}$ Banking Model was developed in Bangladesh by the economist Muhammad Yunus in $1977 .{ }^{34}$ The first clients were stool makers. ${ }^{35}$ These women used their loan to purchase raw materials, thereby breaking the cycle of subsistence caused by moneylenders charging high rates of interest. ${ }^{36}$ Since its inception, the Grameen Bank has grown to the point of serving 1.8 million needy clients, lending $\$ 30$ million per month. ${ }^{37}$ Pointing to the high rates of repayment, critics within Bangladesh have called on Grameen to move closer to commercial banks and charge lower interest rates. ${ }^{38}$

Inspired by the good news from Bangladesh, programs based on the Grameen model were established throughout the world. ${ }^{39}$ Sponsored by nongovernmental organizations, corporations, and governmental aid programs, these programs appeared both in underdeveloped as well as highly industrialized nations. ${ }^{40}$ Muhammad Yunus's theory was that wherever there was poverty, microcredit could fight it. ${ }^{41}$ The application of microcredit in American urban centers has been turbulent. ${ }^{42}$ Gary Hattem, president of the Deutsche Bank Americas Foundation, for example, expressed concern that the publicity and excitement surrounding microcredit could burn itself out: "Microfinancing has to grow as an industry as a bottom-up strategy. The potential problem is too much enthusiasm and having it explode."43 Another drawback to the American application is that there are many small microlenders “[w]ith limited organizational infrastructure and management teams consumed

30. Id.

31. Fernando, supra note 28 , at 151 .

32. Id.

33. Grameen is the Bengali word for villages. See "Grameen Bank," at http://en.wikipedia.org/wiki/Grameen (last modified Feb. 26, 2006).

34. YUNUS, supra note 18, at 61 .

35. AleX COUNTS, Give Us CREDIT 39 (1996).

36. YUNUS, supra note 18, at 44-56.

37. Basic Facts, supra note 29.

38. Hasina-Microcredit, UNITED NEWS OF BANGLADESH, Feb. 19, 2004.

39. See YUNUS, supra note 18, at 155.

40. See, e.g., Bruce Clark, Big Role for the Small Loan, Fin. Times (London, England), Feb. 6, 1997, at 3 .

41. YUNUS, supra note 18 , at 175.

42. See Valjean McLenighan \& Jean Pogge, The Business of Self-Sufficiency: MICROCREDIT PROGRAMS IN THE UNITED STATES 8 (1991) (listing common problems experienced in U.S. programs).

43. Adrian Murdoch, Value for Money: Microfinancing Can Change the Way Poorer Populations Develop, 14 WorLdLINK 52 (Sept. 1, 2001) (quoting Stephanie Lowell). 
by an incessant search for funding ....,44 These lenders devote little time to improving effectiveness or growth. ${ }^{45}$ As a result, more than $40 \%$ of American microlenders have annual budgets under $\$ 100,000$, and these groups work in isolation and often duplicate each other's efforts. ${ }^{46}$

There are several theories to account for the success of microcredit. ${ }^{47}$ First, the reliance on peer pressure or other social and religious norms prove to be as effective an incentive for repayment as traditional physical collateral. ${ }^{48}$ Second, microlenders succeed where there is a "credit-conducive culture," a theory tested in markets where there is a high degree of consumer credit and indebtedness, such as the United States. ${ }^{50}$ Third, conventional financial wisdom may simply have miscalculated the need or profitability of microlending and the ability of the poor to repay their debts. ${ }^{51}$ Furthermore, three factors have been advanced to account for the Grameen Bank's success in Bangladesh: it serves the extremely poor; it can be used by the poor, who are often illiterate and uneducated; and the rigidity of its rules prevents cooption and subversion by local elites. ${ }^{52}$ Theories explaining the initial success of microcredit in the United States are explored below. ${ }^{53}$

\section{Grameen I}

Under the original Grameen system, banks are responsible for territories of fifteen to twenty-two villages. ${ }^{54}$ The bank workers familiarize themselves with the villagers and assess their needs. ${ }^{55}$ Peer groups of five unrelated individuals ${ }^{56}$ are formed from each of the villages. ${ }^{57}$ At this stage, these groups are potential borrowers. ${ }^{58}$ Membership is limited to persons whose net worth is less than the equivalent of one-half acre of land. ${ }^{59}$ Only two of the five are

44. Id.

45. Id.

46. Id.

47. Jameel Jaffer, Microfinance and the Mechanics of Solidarity Lending: Improving Access to Credit Through Innovations in Contract Structure, 9 J. TRANSNAT'L L. \& POL'Y 183, 186 (1999).

48. Id.

49. Id.

50. See Justin Lahart, Spending Our Way to Disaster: The Consumer Debt Bubble in the United States Could Make the Stock Bubble Look Like Nothing, CNN/MONEY, Oct. 3, 2003, available at http://money.cnn.com/2003/10/02/markets/consumerbubble/.

51. Jaffer, supra note 47 , at 186.

52. Philip M. Nichols, Swapping Debt for Development, 27 N.Y.U.J. INT'LL. \& PoL. 43, 74-78 (1994).

53. See id. at Section II-B.

54. Lending Models, supra note 19.

55. Id.

56. Jaffer, supra note 47 , at 198.

57. Lending Models, supra note 19.

58. Id.

59. Jaffer, supra note 47 , at 198. 
eligible to receive funds. ${ }^{60}$ The local bank observes the borrowers for a month to ensure that they are adhering to the lending rules. ${ }^{61}$ Only if these original borrowers successfully repay their loans and interest do other members of the group become eligible. ${ }^{62}$ The typical life of a Grameen loan is fifty weeks, which produces an interesting symbiotic effect between the borrowers and potential borrowers within the group. ${ }^{63}$ During this time, the other members exert substantial pressure to guarantee that the original loans are repaid. ${ }^{64} \mathrm{On}$ the other hand, the economic benefit the borrowers derive serves as an incentive for the others to remain in the program. ${ }^{65}$ Interest rates on Grameen loans range between sixteen $^{66}$ and twenty percent. ${ }^{67}$

Despite the greater individual isolation and potential mobility of poor urban Americans, this double mechanism of peer lending has also worked in the United States. ${ }^{68}$ When pressed about delinquency rates, the director of Project Enterprise, a microcredit program operating in Harlem and Brooklyn, New York and serving a predominantly African American female clientele, indicated the project's total current default amount was $\$ 202$, and that one client had been delinquent, "but we got the money in the end. It was not just a bank going after the money, it was her peers too.",69

\section{Grameen II}

In 2002, Muhammad Yunus and the Grameen Bank developed the Grameen Generalized System, commonly referred to as GGS, or Grameen II. ${ }^{70}$ GGS was viewed as an adaptive improvement upon the original system. ${ }^{71}$ It added four new characteristics to the original framework: loan flexibility, pension plans, self-guaranteed loan insurance, and the community star system. ${ }^{72}$ Not all of these can be easily transferred to an urban American context.

Precipitated by a devastating cyclone in $1998,{ }^{73}$ Grameen II introduced flexibility to the original Grameen framework, thereby protecting borrowers

60. YUNUs, supra note 18, at 63.

61. Lending Models, supra note 19.

62. Id.

63. See id.

64. Id.

65. Id.

66. Jaffer, supra note 47, at 198.

67. YUNUS, supra note 18, at 68.

68. Murdoch, supra note 43.

69. Id.

70. YUNUS, supra note 18, at 237.

71. Id.

72. Id. at 237-43; see also Muhammad Yunus, Grameen Bank II Designed to Open New Possibilities, at http://www.grameen-info.org/bank/bank2.html (last modified Sept. 13, 2003) (updating developments of the Grameen Generalized System as of October 2002) [hereinafter Grameen II].

73. Grameen II. 
from unforeseen crises, and insulating the bank from failure. ${ }^{74}$ Under this new loan regime, borrowers who find themselves in financial straits can get a "rescheduled basic loan with its own separate set of rules." While this innovation makes a certain amount of sense, critics have pointed to it as an example of bookkeeping legerdemain that inflates the touted repayment rates. ${ }^{76}$ To the Bangladeshis in need of help, this criticism is irrelevant. It is important to keep in mind, however, that American microlenders do not necessarily practice this form of rescheduling, which in turn may contribute to higher default rates. $^{77}$

The second and third innovations are the introduction of pension plans and self-guaranteed loan insurance, the applicability of which to the urban American microcredit market will be explored elsewhere. ${ }^{78}$ Basically, all Grameen borrowers with a loan greater than a certain fixed amount must contribute to a pension fund. ${ }^{79}$ Unlike the American social security system, borrowers who contribute to the general fund are guaranteed a set amount after ten years when their pension account matures. ${ }^{80}$ The rate of return is envisaged to be nearly $200 \%$. $^{81}$

Self-guaranteed loan insurance was developed to address the fear of borrowers that their debt might remain after they die. ${ }^{82}$ Here, the borrower contributes $2.5 \%$ of the outstanding amount on the last day of each calendar year. ${ }^{83}$ Should the borrower die during the following year, the debt is paid out of the general fund and the borrower's survivors are refunded all contributions to the fund the borrower made. ${ }^{84}$ If the borrower outlives her loan, then the contributions are not refunded. ${ }^{85}$ This, perhaps, serves as an incentive for the bank and its branches to take a greater interest in the community and work toward an increased standard of living for their villages.

74. YUNUS, supra note 18, at 238.

75. Id.

76. See Harry Hurt, A Path to Helping the Poor, and his Investors, N.Y. TimEs, Aug. 10, 2003 , at 3-4.

77. Cf. Murdoch, supra note 43. "The way that some organisations report defaulted loans also raises eyebrows ... continuing transparency in the sector is crucial." Id. (internal citation omitted). See also Elaine Edgcomb et Al., The Practice of Microenterprise In the U.S.: STRATEGIES, COSTS, AND EFFECTIVENESS 52 (1996) (noting that default rates for the period of the study, 1992-94, have commonly been above $10 \%)$.

78. See infra Section II.

79. YUNUS, supra note 18, at 240.

80. Id.

81. Id.

82. This fear apparently arises primarily out of concern that the soul will not be at rest, rather than the more temporal fear that the family might be forced to assume the debt. See id. at 241.

83. Id. In this respect, the system resembles the Muslim practice of mudaraba. See infra Part II.B.

84. YUNUS, supra note 18 , at 241.

85. Id. 
As a means of both improving village conditions and monitoring those improvements, Grameen II includes a five-star registration component. ${ }^{86}$ Each star represents a separate achievement for the branch and its villages. ${ }^{87} \mathrm{~A}$ green star represents a zero percent default rate. ${ }^{88}$ A blue star represents a branch turning a profit. ${ }^{89}$ A violet star represents a branch with a deposit surplus greater than its outstanding loans. ${ }^{90}$ A brown star represents a branch that ensured an education for $100 \%$ of its borrowers' children. ${ }^{91}$ Finally, a red star represents a branch that succeeded in bringing $100 \%$ of its borrowers above the poverty line. ${ }^{92}$ At the end of 2002, there were 1,178 Grameen bank branches operating in Bangladesh. ${ }^{93}$ Of this number, 772 earned a total of 1,346 stars, or 1.74 stars per branch. ${ }^{94}$ Staff members earn their stars according to the achievements of the lending centers for which they are responsible. ${ }^{95}$ These stars are a matter of pride and social status ${ }^{96}$ - there is no monetary advantage in receiving them. ${ }^{97}$

\section{B. Venture Philanthropy and the International Focus}

In his address to delegates at a microcredit conference held in London, Muhammad Yunus proclaimed: "[P]overty does not belong in a civilised human society. It belongs in museums." 98 While this sentiment is shared by activists, NGOs, and the United Nations, the costs involved in relegating poverty to the collective world memory are staggering. ${ }^{99}$ It was estimated that $\$ 21.6$ billion would be required to expand microcredit initiatives to the 100,000 poorest families by $2005 .{ }^{100}$ As Carter Garber, a development consultant from the United States, points out, such a goal is a "very steep challenge."101 In the period 1987 to 1997 , microcredit proponents raised only five hundred million dollars in private funds. ${ }^{102}$

86. Id. at 242 .

87. Id.

88. There were 696 green stars awarded in 2002. Id. at 242 .

89. There were 437 blue stars awarded in 2002 . Id.

90. There were 213 violet stars awarded in 2002. Id.

91. Sixty-one branches applied for brown stars in 2002 . Id.

92. Twenty-one branches applied for red stars in 2002. Id. at 243. It is unclear whether the indicated poverty line is national or international. $I d$.

93. Id.

94. Id. at 243.

95. Grameen II, supra note 72 .

96. Id.

97. A similar program could be introduced on a state or federal level in the United States, with each star earned translating directly into tax credits or some other benefit for the sponsor bank and microlender.

98. Clark, supra note 18 , at 3.

99. Id.

100. Id.

101. Id

102. Id. 
Fortunately, private donations are not the only source of funding that microcredit enjoys. ${ }^{103}$ The U.S. government and various corporate charitable foundations provide support and guidance to microcredit initiatives. ${ }^{104}$ However, the focus of this support has been primarily on foreign aid. For example, one of the motivations behind the Microenterprise for Self Reliance and International Anti-Corruption Act of $2000^{105}$ was a push by Congress to "reaffirm[] the traditional humanitarian ideals of the American people and renew[] its commitment to assist people in developing countries to eliminate hunger, poverty, illness, and ignorance."106

Domestically, a large amount of microcredit funding has gone to the assistance of refugee resettlement within the United States. ${ }^{107}$ In fiscal year 2000 , the Office of Refugee Relocation awarded $\$ 2,850,851$ to develop and administer microenterprise programs for the benefit of refugees. ${ }^{108}$ These programs were intended not only to aid in the resettlement of newly arrived non-citizens, but also to aid refugees who have been in the United States for a number of years and who seek microcredit as a means to supplement their incomes. ${ }^{109}$ This is not to gainsay the importance of such foreign investment; in fact, one proponent has suggested that microcredit, with its twin goals of economic opportunity and poverty alleviation, is the most effective way to wage a war against terrorism. ${ }^{110}$ Under the Clinton presidency, the Small Business Administration (SBA) expanded its microcredit initiatives. ${ }^{111}$ By 1997, the SBA had awarded $\$ 70$ million in grants to nonprofit organizations. ${ }^{112}$ The loans ranged in amount from $\$ 125$ to $\$ 15,000$, with half of the loans awarded to women. ${ }^{113}$ This progress has been subsequently imperiled by current

103. See Fbout FIELD: Advisory Board,
http://www.fieldus.org/about/advisory_board.html (last visited Mar. 20, 2006) (FIELD, a
national board of microlenders, lists among its donors the Charles Stewart Mott Foundation,
Citigroup Foundation, the Ford Foundation, the Levi Strauss Foundation, and the U.S. Small
Business Administration).

4. Id.

105. 22 U.S.C.S. $\$ 2151$ (2005).

106. $I d$.

107. 2000 Off. of Refugee Resettlement Ann. Rep., available at http://www.acf.dhhs.gov/programs/orr/policy/00arc6.htm (last updated Sept. 26, 2002).

108. Id.

109. Id. See, e.g., PEGgy Clark ET AL., MicroenterPRISE AND THE POOR: FINDINGS FROM THE SElfF-EMPLOYMENT LEARNINg PROJECT, FIVE YeAR SURVEY OF MICROENTREPRENEURS vi-vii (1999) (indicating a parallel practice of income patching among urban microentrepreneurs).

110. Hurt, supra note 76, at 4. (quoting Alexandre de Lesseps, co-founder of BlueOrchard Finance and "one of the leading figures in the world of microfinance. . . .) "The only way to solve the problems of poverty and terrorism in the world today . . . is through investment." Id.

111. Taibi, supra note 16 , at 1527.

112. Hillary Clinton, Remarks at the Microcredit Summit, Washington, D.C. (Feb. 6, 1997). 113. Id. 
economic policies: ${ }^{114}$

The Bush administration removed the Small Business Association from the cabinet and proposed cutting the agency's funding by over 20 percent. Worse, it aims to reduce the agency's lending capacity by 50 percent. [In 2002], there is $\$ 9.4$ billion available for small-business loans guaranteed by the agency. For [2003], the administration is proposing less than $\$ 5$ billion. ${ }^{115}$

To fill this breach, a new force has emerged: the venture philanthropist. Under this paradigm, philanthropists are to "think like businesspeople."116 They should seek out efficiency and innovation, and not merely cut a check to a worthy cause. ${ }^{117}$ While the idea of using market forces to affect social change is "anathema" to some, ${ }^{118}$ venture philanthropy has won some high profile proponents. ${ }^{119}$ Of the approximately 3,000 microcredit programs operating worldwide, seventy percent serve fewer than 2,500 clients. ${ }^{120}$ Part of what motivates private investors such as Vinod Khosla, co-founder of Sun Microsystems, ${ }^{121}$ are the images of personal triumph over poverty: "I was completely blown [away] as I listened to the stories of these tenacious women . . . I started crying."122 As far as investment potential, microcredit programs might not be "as profitable as Google, but they have the same level of social impact." 123 Such endorsements bring significant attention to microcredit, and investors such as Khosla afford microcredit programs to grow beyond the current levels. $^{124}$

A more muted investment outlook is expressed by Alexandre de Lesseps, ${ }^{125}$ founder of BlueOrchard, a Swiss microcredit investment

114. See Fred P. Hochberg, American Capitalism's Other Side, N.Y. TIMES, July 25, 2002, at $\mathrm{A} 17$ (the author was deputy and then acting administrator of the Small Business Administration from 1998 to 2001).

115. Id.

116. In 2005, How to Align Your Money with Your Values, Christian SCI. Monitor, Jan. 24, 2005, at 13 [hereinafter How to Align].

117. Id.

118. Murdoch, supra note 42.

119. How to Align, supra note 116 (Charles Harper, executive director of the John Templeton Foundation outline venture philanthropy and lists VISA and MBNA as groups currently involved). C3.

120. Saritha Rai, Tiny Loans Have Big Impact on Poor, N.Y. TIMES, April 12, 2004, at

121. Vinod Khosla, WIKIPEDIA: THE FREE ENCYCLOPEDIA, at http://en.wikipedia.org/wiki/Vinod_Khosla (last modified Mar. 6, 2006).

122. Rai, supra note 120 , at 3 .

123. Id.

124. Id.

125. Hurt, supra note 76 , at 4 . 
consultancy firm. ${ }^{126}$ Microfinance investment is not a way to accumulate rapid sums of wealth, but with an average return of four percent, it outperforms money market accounts and is safer than the market. ${ }^{127}$ "If you're a blue-chip investor sitting on a lot of cash, it makes sense to put up to [four] percent of your net worth into this type of fund." 28 De Lesseps also stresses the satisfaction derived from aiding in the alleviation of world poverty. ${ }^{129}$ Much of the excitement surrounding microcredit is not only its perceived novelty, but the promise that current efforts will "become one of the great humanitarian movements of history, allowing people to free themselves from the bondage of poverty." 130

As seen in the comments above, microcredit is widely viewed as a program with global, specifically Third World, applications. Microcredit in the United States remains in the early stages of its development. ${ }^{131}$ Venture philanthropy may not be able to provide the same support to U.S. programs as it can in nations such as Bangladesh or Sri Lanka. Venture capital generally retains an equity interest in the companies it funds, ${ }^{132}$ which in turn might reduce local control and work against those characteristics which contribute to the success of urban microcredit, such as a sense of community and local responsibility. ${ }^{133}$ Also, venture capital might prefer companies that can demonstrate "significant unrealized market potential or the ability to develop new markets" 134 rather than microentrepreneurs, who require ongoing training and support to succeed. ${ }^{135}$

126. BlueOrchard Finance s.a. - Microfinance Investment Advisers, at http://www.blueorchard.ch/en/home.asp (n.d.) (last visited Mar. 20, 2006).

127. Hurt, supra note 76 , at 4 .

128. Id.

129. Id.

130. Fernando, supra note 28 , at 159.

131. See generally CLARK, supra note 109 , at viii (describing some of the problems U.S. programs have experienced and certain adaptations they have undertaken).

132. JONES, supra note 1 , at 77 .

133. EDGCOMB, supra note 77, at 5.

134. JONES, supra note 1 , at 77.

135. See CLARK, supra note 109, at viii. "Low-income entrepreneurs need ongoing technical assistance and specialized consulting to help them implement and grow their businesses." Id. 


\section{MICROCREDIT IN THE UNITED STATES}

\section{A. Microfinance ${ }^{136}$ in the Fringe Lending Context}

Microentrepreneurs and, more generally, consumers often face insurmountable hurdles in their quest for credit: they lack credit histories, their credit is poor, their income is low, or they have a high debt-to-income ratio. ${ }^{137}$ Furthermore, their needs are often so relatively small that the cost of application review, credit checks, and processing makes extending loans prohibitively expensive for traditional banks. ${ }^{138}$ Banks usually do not make loans for less than $\$ 25,000$. $^{139}$ Several legal and illegal options rise to fill the credit vacuum, all of which offer credit at great cost. ${ }^{140}$ This situation depresses the opportunities of the individual credit-seeker, the credit-seeker's family, and, in the aggregate, the credit-seeker's community. ${ }^{141}$

The lack of available credit is also poignantly felt among immigrants. ${ }^{142}$ The situation has become increasingly difficult for legal immigrants, in particular, who face cuts in food stamps and restricted forms of social services and public services during the first five years of their residency in the United States. ${ }^{143}$ For those immigrants wishing to start businesses but who are ineligible for microloans under the program offered by the Office of Refugee Resettlement of the Department of Health and Human Services, loansharks are often the only option. ${ }^{144}$ An entrepreneur in Williamsburg, New York reported

136. Non-profit and government entities in the United States prefer such terms as "microfinance," "microenterprise," and "microentrepreneur" to the internationally used term "microcredit." See id. The difficulty of finding evidence to support this proposition directly is perhaps attributable to a semantic choice designed to remove the stigma of charity or entitlement from these programs. See id.

137. James P. Nehf, Secured Consumer Credit and the Fringe Banking Industry (manuscript, on file with author).

138. Id.

139. Leslie Eaton, Minor Loans Giving Major Help, Microcredit Catches on with Entrepreneurs in Need, N.Y. Times, July 11, 1998, at B1.

140. Nehf, supra note 136 , at 2 .

141. See Clinton, supra note 112.

142. See Housing Counseling: Hearing Before the Subcomm. on Housing \& Community Opportunity of the House Comm. on Financial Services, 108th Cong. 120 (Mar. 18, 2004) (statement of Kenneth D. Wade, Executive Director, Neighborhood Reinvestment Corporation), at http://financialservices.house.gov/media/pdf/108-73.pdf. "Many minority families, particularly immigrants, lack the information and familiarity with mainstream financial institutions, which makes them vulnerable targets for high cost loans and predatory lending practices." Id.

143. JONES, supra note 1, at 44.

144. See, e.g., Eaton, supra note 139, at B1; see also Laura Sydell, Mexican Immigrants Use Money-Lending System Known as a Tanda to Start Small Business, (Nat'l Pub. Radio Broadcast, Aug. 9, 2004) [hereinafter Tanda]. 
that loansharks there charged $\$ 200$ per month on a $\$ 1,000$ loan, an interest rate of $140 \%$ per annum. ${ }^{145}$

In addition to overtly coercive fraudulent money-lending operations, such as loansharks, there are subtler swindlers that either resemble traditional finance arrangements common in immigrant communities, or appear facially harmless. The most common frauds are the Ponzi scheme ${ }^{146}$ and its derivative versions. Basically, investors are promised artificially high dividends when, in fact, new investors' contributions provide the dividends of earlier investors. ${ }^{147}$ There is usually no actual capital production other than continually raising new funds. ${ }^{148}$ A variation of the Ponzi scheme is the pyramid, or airplane, ${ }^{149}$ scheme in which investors receive compensation for bringing in new investors. ${ }^{150}$ Like the Ponzi scheme, pyramid schemes are illegal in most states. ${ }^{151}$ Another version is the birthday club ${ }^{152}$ in which new recruits make gifts of money to current members under the impression that future recruits will in turn make gifts of money to them. ${ }^{153}$ Interestingly, many such clubs limit membership to women. ${ }^{154}$

Generally, Ponzi schemes do not represent as great a threat to microfinance operations, as they generally involve smaller amounts of money because, if the victims were required to put up large sums of money to participate, it is unlikely that they would need the services of a microlender. ${ }^{155}$ There is room for a certain amount of confusion of Ponzi schemes with their legitimate cousin, the rotating savings and credit association (ROSCA). Essentially, a ROSCA is a group of individuals who come together to make regular contributions to a joint fund. ${ }^{156}$ The joint fund is then distributed to one member of the group who then repays the loan in further monthly

145. Eaton, supra note 139 , at B1.

146. "This scheme takes its name from Charles Ponzi, who in the late 1920s was convicted for fraudulent schemes he conducted in Boston.” BLACK's LAW DictionaRY 1198 (8th ed. 2004).

147. Id.

148. Id.

149. An airplane scheme is simply a pyramid scheme with titles assigned to the investors such as pilot, co-pilot, navigator, stewardess, passenger, depending on how close the investor is to winning a pay-out. See, e.g., New York v. Riccelli, 540 N.Y.S.2d 74 (1989).

150. Black's Law Dictionary 1272 (8th ed. 2004).

151. Id. See, e.g., IND. CodE ANN. \& 35-45-5-2 (2004); 815 ILL. CoMP. STAT. ANN. 505/1 (2004); CAL. PENAL CODE $\$ 327$ (2006) (all three illustrating laws against illegal gambling and fraudulent investment schemes, none of which resemble the basic mode of Grameen microcredit).

152. Jennifer Coleman, Sacramento Authorities Probe Pyramid Scheme, AssociaTED Press, Oct. 23, 2002, available at Berkeley Daily Planet, http://www.berkeleydailyplanet.com/article.cfm?archiveDate=10-23-02\&storyID=15584.

153. BLACK's LAW DictionaRY 710 (8th ed. 2004).

154. Id. id.

155. This, however, might not be the case in smaller-stake Ponzi or pyramid schemes. See

156. Lending Models, supra note 19. 
contributions. ${ }^{157}$ "Deciding who receives the lump sum is done by consensus, by lottery, by bidding or other agreed methods." 158 Such arrangements are common in Mexican immigrant communities, where they are known as tandas. ${ }^{159}$ Tandas are often administered privately, as members may be undocumented. ${ }^{160}$ This reluctance to turn to the authorities for help increases the risk that members of a tanda will fall victim to fraud, but such occurrences are apparently rare. ${ }^{161}$ Professor Carlos Velez-Ibanez, a professor of anthropology at the University of California, Riverside, who studies tandas, describes a group cohesion similar to the peer pressure mechanism that drives repayment under Grameen microlending:

If you bug out on somebody, all of the other relationships also vibrate. That is, your cousin's going to know about it, your aunt's going to know about it, the people that you go to school with are going to know about it and your reputation then goes down the tubes and you won't be invited to the wedding, to the baptism or to Aunty Maria's 50th golden anniversary. ${ }^{162}$

Other groups use ROSCAs similar to the tanda to start and maintain small businesses; Caribbean cultures call the arrangement en susu and the Vietnamese hui. ${ }^{163}$ Korean and Ethiopian immigrants also have similar financial programs. ${ }^{164}$ While these immigrant ROSCAs resemble Grameen microlending in form and function, it should be kept in mind that these groups are typically no larger than ten to fifteen persons, ${ }^{165}$ and each group has no support beyond its membership. ${ }^{166}$

Proponents of microcredit urge that it is equally applicable in the United States as it is in rural South Asia. ${ }^{167}$ Others do not believe the transition will be so smooth. ${ }^{168}$ Two separate studies have shown impressive gains made by poor microentrepreneurs vis-à-vis control groups composed of non-poor microentrepreneurs and poor people who did not participate in microcredit

157. Id.

158. Id.

159. Tanda, supra note 144.

160. Id.

161. Id.

162. Id.

163. Id. See, e.g., ROSCAs: Whats in a Name?, available at http://www.gdrc.org/icm/rosca/rosca-names.html (n.d.) (last visited Mar. 20, 2006) (listing common names for ROSCA arrangements by continent and country).

164. Eaton, supra note 139, at B1.

165. Tanda, supra note 144 .

166. See id. (noting the low profile and self-sufficient nature of tandas.).

167. Clinton, supra note 112.

168. Cf. Eaton, supra note 139, at B1. Robin A.E. Ratcliffe, a vice-president of ACCION International said, "Some people thought that you could take [the Grameen] model, go clunk and make it work here . . but that is not our experience." Id. 
programs. ${ }^{169}$ Before examining those studies, this Note will address the general development of microfinance in the United States.

Microfinance is often defined in the United States as "a sole proprietorship, partnership or family business that has fewer employees, [without] access to the commercial banking sector, [utilizing] a loan of less than $\$ 25,000$ to start or expand a business that usually grosses less than $\$ 250,000$ per year." 170 In fact, "microenterprise development" covers a vast spectrum of programs that reflect the purposes and values of their designers and clients. ${ }^{171}$ "Over 750 microenterprise programs and supporting programs now exist in all 50 states, the District of Columbia, the Mariana Islands and Puerto Rico. In 2000 , the majority of these programs assisted 99,945 individuals, of which 9,800 were borrowers." ${ }^{172}$ There are an estimated two million microentrepreneurs currently working in the United States. ${ }^{173}$ Self-employment has grown in prominence due to layoffs and downsizing in the current U.S. economy. ${ }^{174}$

Microfinance in the United States resonates with the American psyche, ${ }^{175}$ even though the benefits of microfinance manifest themselves in largely unpredictable ways. ${ }^{176}$ Perhaps the most important side-effect of microfinance, especially where it allows a family to move out of poverty, is the ability to accumulate wealth. This, in turn, leads to, among other things, improved household stability, an increase in social and political participation and influence, and an enhancement of child welfare. ${ }^{177}$ Furthermore, microcredit provides the means for some to break the cycle of economic dependency and poverty by providing both economic literacy and self-esteem. ${ }^{178}$ This in turn leads to family and community development. ${ }^{179}$

Despite these optimistic possibilities, some observers have noted that it is irresponsible to expose poor people to the vagaries of market economics, ${ }^{180}$ especially when moving from government assistance to self-employment may

169. See generally CLARK, supra note 109, at v; EDGCOMB, supra note 77, at 2; MCLENIGHAN, supra note 42, at 2-4.

170. Susan R. Jones, Representing the Poor and Homeless: Innovations in Advocacy Tackling Homelessness Through Economic Self-Sufficiency, 19 ST. LOUIS U. PUB. L. REV. 385, 389 (2000).

171. JONES, supra note 1 , at 2.

172. Id.

173. CLARK, supra note 109 , at 4 .

174. Susan R. Jones, Small Business and Community Economic Development: Transactional Lawyering for Social Change and Economic Justice, 4 CLINICAL L. REV. 195, 201 (1997).

175. CLARK, supra note 109 , at iv.

176. Id. at 68.

177. Id. at 20 (quoting Michael SHERraden, Assets AND the POOR: A NEW AMERICAN WELFARE POLICY 294-95 (1991)).

178. Jones, Representing the Poor and Homeless, supra note 170, at 394.

179. JONES, supra note 1 , at ix.

180. Cf. Murdoch, supra note 43 (noting the perceived irresponsibility of exposing the world's poor to market forces rather than the U.S. poor). 
mean a loss of medical coverage. ${ }^{181}$ Proponents counter that microenterprise "represent[s] a responsible hybrid of business and social welfare institutions." 182

Described as "the new public interest law," revitalizing potential that goes beyond mere banking. It is "not simply an economic issue; it is also a moral issue." of self-employment coupled with community empowerment. ${ }^{185}$ While the original programs were marketed to women, ${ }^{186}$ microfinance has expanded to serve women and men, who in turn work together to build stronger communities. ${ }^{187}$ Furthermore, the training and technical assistance that microfinance programs provide, which are the most expensive components of the programs, ${ }^{188}$ are also the most important, especially for low-income clients. ${ }^{189}$ By addressing poverty through attacking the credit gap, these programs build people as well as businesses. ${ }^{190}$ Among the disparate groups microfinance programs have assisted are immigrants and refugees, ${ }^{191}$ domestic violence survivors, ${ }^{192}$ physically disabled persons, ${ }^{193}$ ex-offenders reentering society, ${ }^{194}$ and homeless persons. ${ }^{195}$

One of the difficulties facing the domestic application of microfinance programs is the higher level of regulation and red tape in the United States than abroad. ${ }^{196}$ At the federal level, microfinance programs must contend with IRS regulations, ${ }^{197}$ the Community Block Grant Development Program, ${ }^{198}$ as well as a litany of consumer laws. ${ }^{199}$ The current administration's "faith-based initiatives" experiment provides a further level of complexity. ${ }^{200}$ Most

181. See, e.g., CLARK, supra note 109 , at 25.

182. Taibi, supra note 16 , at 1527.

183. Jones, Small Business, supra note 174, at 200.

184. JONES, supra note 1 , at 3.

185. Id.

186. But see The WSEP Strategy, at http://www.wsep.net/About.htm (on file with author) (The Women's Self-Employment Project was founded to serve women and still maintains that mission).

187. Clinton, supra note 112.

188. MCLENIGHAN, supra note 42 , at 10 .

189. Jones, supra note 170 , at 398.

190. MCLENIGHAN, supra note 42 , at 10.

191. JONES, supra note 1, at 50-54.

192. Id.

193. Id. at 56.

194. Id. at 57-61.

195. Id. at 61.

196. MCLENIGHAN, supra note 42 , at 9 .

197. JONES, supra note 1, at 25-28.

198. Id. at 16.

199. Id. at 33 .

200. See id. at 65 . "[F]aith-based initiative has raised many legal and policy questions... [yet] faith-based microenterprise members are doing some of the best work in maintaining the focus on poverty alleviation as the most important impact of U.S. microenterprise efforts." Id. (internal quotation marks omitted). 
microlending programs are organized as tax-exempt charitable or educational entities under section 501(c)(3) of the Internal Revenue Code. ${ }^{201}$ In order to qualify for 501(c)(3) status, the program must be "organized and operated exclusively for ... charitable ... or educational purposes."202 The word "charitable" comprises "relief of the poor and distressed or of the underprivileged, advancement of education, and promotion of social welfare through organizations formed to lessen neighborhood tensions, eliminate prejudice and discrimination, or combat deterioration or juvenile delinquency.",203

The Community Block Grant Development Program, which involves grants of aid from the Department of Housing and Urban Development ${ }^{204}$ to "carry out a wide range of community development activities directed toward revitalizing neighborhoods, economic development, and providing improved community facilities and services," 205 now recognizes microfinance programs as eligible recipients. ${ }^{206}$ However, some groups are reluctant to accept federal monies out of concern over the loss of local control. ${ }^{207}$

Other statutes that affect microenterprise programs deal with consumer law and credit-reporting practices. ${ }^{208}$ The Truth in Lending Act (TILA) ${ }^{209}$ concerns the computation of annual lending rates and how this information is communicated to the consumer. ${ }^{210}$ The Equal Credit Opportunity Act $(E C O A)^{211}$ ensures that women are extended credit on the same terms as men, regardless of their marital status. ${ }^{212}$ The Fair Credit Billing $\mathrm{Act}^{213}$ outlines the procedures used in dealing with complaints about customer billing. ${ }^{214}$ The Fair

201. Id. at 25 .

202. Id. at 27.

203. Id. at 27-28.

204. United States Department of Housing and Urban Development, at http://en.wikipedia.org/wiki/United_States_Department_of_Housing_and_Urban_Development (last modified Mar. 1, 2006).

The United States Department of Housing and Urban Development, often abbreviated HUD, is a Cabinet department of the United States government. It was founded in 1965 to develop and execute policy on housing and cities. It has largely scaled back its urban development function and now focuses primarily on housing.

Id.

205. Community Development Block Grant Entitlement Communities Overview, at http://www.hud.gov/offices/cpd/communitydevelopment/programs/entitlement/index.cfm (last updated Dec. 15, 2005).

206. JONES, supra note 1 , at 16.

207. Telephone Interview with Jonathan Brereton, Chief Financial Officer, ACCIÓN Chicago (Oct. 14, 2004) [hereinafter Brereton Interview].

208. JONES, supra note 1 , at 33 .

209. 15 U.S.C. $\S 1601$ (2005).

210. JONES, supra note 1 , at 33.

211. 15 U.S.C. $\$ 1691$ (2005).

212. JONES, supra note 1 , at 33 .

213. 15 U.S.C. $\$ 1666(2005)$.

214. JONES, supra note 1 , at 33 . 
Debt Collection Practices Act (FDCPA or FDCA) ${ }^{215}$ outlines appropriate and inappropriate debt collection methods. ${ }^{216}$ The Fair Credit Reporting Act (FCRA) ${ }^{217}$ grants consumers access to their credit records and affords them opportunities to correct incorrect information. ${ }^{218}$

At the state level, microfinance programs must be aware of moneylender licensing and charitable solicitation licensing requirements, as well as usury laws. ${ }^{219}$ While lender liability suits are rare, microfinance organizations often have to contend with various legal issues. ${ }^{220}$ Aside from more mundane legal problems, such as breach of contract claims against distributors, ${ }^{221}$ some programs have inquired as to their liability should the repayment peer pressure turn tortious. ${ }^{222}$

In Hawthorne v. Olympia Fields, ${ }^{223}$ the Women's Self Employment Project entered as amicus curiae on behalf of a client who sought a zoning change to allow her to conduct a child daycare business. This case was critical because it not only affected microentrepreneurs' ability to work in one of the more popular spheres of microenterprise, but it also affected microentrepreneurs in need of child care. The "WSEP's interest in home-based child care stems from a desire to provide quality child care for low-income women, thereby helping welfare recipients become self sufficient, and from helping welfare recipients and other low-income women achieve a living wage through work as a home day care provider."224

In the case at bar, Sonya and Marcus Hawthorne purchased a house in Olympia Fields (the Village), intending to use it as a day care facility. ${ }^{225}$ The Illinois Department of Children and Family Services approved their license, but the Village denied them a zoning permit. ${ }^{226}$ The Village cited the fact that daycare facilities were outside the "home occupation" exception of businesses allowed in residential zones. ${ }^{227}$ Businesses falling outside of the "home occupation" exception include "[o]ffices, clinics, doctors' offices, hospitals, barbershops, beauty parlors, dress shops, millinery shops, tearooms, restaurants, tourist homes, animal hospitals and kennels, among other things[.] ${ }^{, 228}$ Because

215. 15 U.S.C. $§ 1692$ (2005).

216. JONES, supra note 1 , at 33 .

217. 15 U.S.C. $\$ 1681$ (2005).

218. JONES, supra note 1 , at 33 .

219. Id. at 29-33.

220. Id. at 32 .

221. Brereton Interview, supra note 207.

222. JONES, supra note 1 , at 32 .

223. Hawthorne v. Olympia Fields, 765 N.E.2d 475 (III. App. Ct), aff'd, 790 N.E.2d 832 (III. 2003).

224. Brief of Amici Curiae Voices of Illinois Children et al., at 10, Hawthome v. Olympia Fields, 765 N.E.2d 475 (IIl. App. Ct. 2002) (No. 1-01-447).

225. 790 N.E. $2 d$ at 835 .

226. Id.

227. Id.

228. Id. This list would exclude a large number of microenterprises from the Village. Id. 
this effectively meant that the Hawthornes could not open a state-licensed daycare facility anywhere within the limits of the Village, the zoning ordinance was "null and void" under Illinois law. ${ }^{229}$ Other than the court mentioning WSEP specifically, ${ }^{230}$ there is no indication that this case involves microcredit or women working their way out of poverty. Hawthorne underscores the problems microentrepreneurs may face in their transition from welfare to work beyond the typical concerns of funding and training.

\section{A. Findings of Studies of Microfinance in the United States}

The earliest study this Note considers organizes microlenders in one of two ways: either as a subsidiary of a larger agency or corporation, or as a taxexempt nondepository community development financial institution. ${ }^{231}$ Significantly, microlenders falling in the latter category were unregulated lenders, and investor funds were uninsured. ${ }^{232}$ The majority of groups in the study used the Grameen peer-lending model with loans ranging between $\$ 8,000$ and $\$ 20,000$. $^{233}$ Among the study's findings were the importance of the peerlending model, which was purported to lower operating costs, ${ }^{234}$ as well as the need for microlenders to be acquainted with the needs of their clientele. ${ }^{235}$ "With first-hand knowledge of the local economy, group members are quick to assess the market for, and feasibility of, a business idea and often have valuable insights, connections, and business assistance to offer."236 That being said, the researchers repeat the mantra that has echoed through almost every account of microcredit, except for those written by Muhammad Yunus: Microcredit is not a panacea. ${ }^{237}$ However, "targeted microenterprise development has tremendous potential for reaching deeply into disadvantaged populations.",238

Five years later, the second study reaffirmed the basic values of microcredit: "[r]ather than emphasizing a person's deficiencies when they enter the program, such as their lack of training for a certain job, or low educational attainment levels, microenterprise programs being by recognizing a person's strengths - the skills, aptitudes, interests, and experience that they already have." ${ }^{239}$ Most of the programs studied were funded primarily through

229. Id. at 837 .

230. Id. at 838 .

231. MCLENIGHAN, supra note 42 , at 5.

232. Id.

233. Id. at 12 .

234. Id. at 6.

235. Id. at 7 .

236. Id.

237. Id.; see also Jones, supra note 170, at 392 (noting that criticism of microfinance includes the observation that there are "only a small percentage of possible microentrepreneurs in the U.S. population.").

238. MCLENIGHAN, supra note 42 , at 7.

239. EDGCOMB, supra note 77 , at 1 . 
private philanthropy. ${ }^{240}$ The focus of the various programs remained poverty alleviation, but there was also a "strong emphasis on client self-selection and client choice."241 Furthermore, a noticeable non-charity approach stressed client responsibility and reliance on market interest rates and repayment standards. $^{242}$

The final study, the Self-Employment Learning Project (SELP), is a culmination of a five-year survey of microentrepreneurs from 1992 to $1996 .{ }^{243}$ The key finding was that more than seventy-two percent of the poor microentrepreneurs "gained in household income during the five-year period, and more than one-half were able to move out of poverty."244 A number of respondents were also able to discontinue government assistance. ${ }^{245}$ Household assets rose by $\$ 13,623$ on average, with the greatest increases among poor respondents $(\$ 15,909)$. One of the more surprising results of the study was the large fraction of households with assets in excess of $\$ 10,000$. $^{246}$ "It is primarily the value of their real estate that accounts for the relatively high level of average assets for these respondents."247 Also, despite their relative income levels, microentrepreneurs who participated in the survey achieved higher average levels of education than microentrepreneurs who were unable to participate, or members of the poor non-microentrepreneur control group. ${ }^{248}$

Beyond these statistics, there are numerous first-hand accounts of how well microcredit can work (even though it cannot work for everyone), including that of Gloria Davis from Chicago, Illinois:

[M] y cousin was an underpaid secretary and I was a welfare mother sewing bridesmaids' dresses at home. All we needed was $\$ 3,000$ to open the dress shop we've been dreaming about since we were kids. But we couldn't get a bank to even talk to us. Thanks to the Women's Self-Employment Project, we are now co-owners of the Neo Emporium. We have determination and a good business plan and with the grace of God, we're going to make it. ${ }^{249}$

240. Id. at 2.

241. Id.

242. Id.

243. ClARK, supra note 109 , at v.

244. Id.

245. See Appendix, tables 2 \& 4.

246. See Appendix, table 1.

247. ClARK, supra note 109, at 21.

248. See Appendix, table 3.

249. MCLENIGHAN, supra note 42, at 3. 
And, more recently, a twenty-three year old microentrepreneur said:

Through a local microenterprise program I learned about how I could start my own business . . . . I had experience cleaning houses for $\$ 25$ a day so I thought, why not start my own business doing that. In my work with the literacy program my reading level increased from the third grade to the eighth grade. I haven't been on welfare in six years. I can read to my kids and we read the Bible everyday. I can now earn $\$ 200$ a day. I make $\$ 48,000$ a year and my goal is to make $\$ 60,000$. I don't panic anymore. I feel great. I have confidence in myself. ${ }^{250}$

Microcredit programs have also reached out to people whose potential might not be as readily apparent as in the examples above. In this case, the success story belongs to a recovering alcoholic homeless veteran:

He is now in the tenth week of Faith Ministry's program where he has learned about marketing, accounting, legal requirements, and business regulations. A volunteer lawyer has agreed to help him structure his business, assist him with getting the appropriate business licenses, and, along with the microenterprise program staff, help him apply for a $\$ 1000$ loan for tools and equipment and business start-up expenses. The lawyer, also a Vietnam Veteran, has agreed to serve as Joe's personal mentor. . . . He attributes his current successes-sobriety, temporary housing, participating in a microenterprise program-to the possibility that he can start something on his own and try to reunite with his family. ${ }^{251}$

Finally, microcredit has also helped noncitizens to strengthen their families and communities:

When Carlos Aldana came to the United States from Ibague, Columbia, 11 years ago, he worked at three jobs ... His first $\$ 1,000$ loan from Accion helped him buy a van to make deliveries; later, larger loans helped him by a tiny café ... and to expand the production of corn cakes known as arepas. Today, Mr. Aldana employs 11 workers in his arepa factory. . 252

250. JONES, supra note 1 , at 50.

251. Jones, supra note 170 , at 388 .

252. Eaton, supra note 139 , at B1. 


\section{B. Microfinance and Welfare Reform}

The SELP study is also the first completed in the wake of Welfare Reform and the enactment of the Personal Responsibility and Work Opportunity Reconciliation Act of 1996 (PRWORA). ${ }^{253}$ Under the previous welfare regime, income caps militated against participation in microcredit programs. $^{254}$ Families receiving Aid to Families with Dependent Children (AFDC) lost their benefits if their assets exceeded $\$ 1,500 .^{255}$ No distinction was made between personal assets and money obtained through loans or the value of capital investment, nor could welfare recipients deduct principal repayments as business expenses. ${ }^{256}$ Since loans were included under the heading of assets, a microloan of $\$ 2,000$ could result in a loss of AFDC benefits. ${ }^{257}$ "It [took] a giant leap of faith for an AFDC mother to forego the security of a monthly welfare check-not to mention Medicaid health coverage for her family."258

The PRWORA dramatically changed the way federal guarantees of assistance to the nation's poorest children had been delivered over the last six decades. 259 "Most notably, the law prohibits states from using federal block grant funds to assist a family for more than five years . . . and requires adults to be engaged in work within two years or receiving assistance, or sooner at the state's option." 260 On the bright side, PRWORA eliminated the federallymandated income exclusions and asset caps that had caused problems under the old regime. ${ }^{261}$ A further advantage of PRWORA and the implementation of state TANF programs are the provisions that grant states broad discretion over microenterprise programs. ${ }^{262}$ Of course, this discretion can be used either advantageously or disadvantageously. For example, states face escalating participation rates in order to avoid TANF penalties. ${ }^{263}$ Not all employment initiatives qualify; therefore, "a state may be hesitant to allow involvement in microenterprise activities unless the state is confident that allowing such activities will not put the state at risk of failing to meet the required participation rate." 264 Also, this does not account for those for whom microcredit programs are not a viable option: estimates place the number of

253. Pub. L. No. 104-193, 110 Stat. 2105 (1996).

254. YUNUS, supra note 18 , at 185.

255. MCLENIGHAN, supra note 42 , at 48.

256. JONES, supra note 1 , at $45-46$.

257. MCLENIGHAN, supra note 42 , at 48.

258. See id. at 48 (1991) (noting the Women's Self-Employment Project's negotiation with the state of Illinois for an annual waiver of the income cap).

259. JONES, supra note 1 , at 44.

260. Id.

261. Id. at 45 .

262. Jones, Representing the Poor and Homeless, supra note 170, at 397.

263. JONES, supra note 1 , at 47.

264. Id. 
welfare recipients who are able to benefit from self-employment at only five to ten percent. ${ }^{265}$

The picture grows dimmer when one considers the non-entrepreneurial working poor in the aftermath of welfare reform. The focus is almost solely on getting people into jobs no matter what the wage or quality of work. ${ }^{266}$ It was estimated that in order for the economy to absorb one million former welfare recipients, the bottom thirty percent of workers, those earning less than $\$ 7.19$ per hour, would suffer an eleven percent wage drop or face displacement. ${ }^{267}$ "The working poor will end up even poorer."268 Microenterprise advocates have developed a number of recommendations to maximize the chances of microenterprise success. ${ }^{269}$ The first calls for a minimum of six months job training and two years business development to be granted to people transitioning from welfare to work. Additionally, training programs should be developed to partner workers with microenterprises to supplement their incomes. ${ }^{270}$ While these are valid recommendations, it has become increasingly important to find ways to extend the reach of successful microcredit programs to aid as many of the working poor as possible. Section III of this Note suggests a means of increasing revenues, counterintuitively, by adopting banking practices that will allow microlenders to lower their interest rates.

\section{Microfinance: Costs and Problems}

Much of the early literature on microcredit mentions the low default rates. ${ }^{271}$ These low default rates and the corresponding claims of selfsufficiency on the part of microcredit programs ${ }^{272}$ appear to be largely illusory. The average loss rate for microloans in the United States is above ten percent. ${ }^{273}$ Microcredit advocates must come to terms with the fact that microcredit is costlier than other forms of credit. ${ }^{274}$ The Edgcomb study reported that the average loan costs $\$ 1.47$ per dollar lent to make and manage the loan, with costs ranging between $\$ 0.67$ and $\$ 2.95 .^{275}$ A board member of a Los Angeles microenterprise program asked, when confronted with a similar

265. Id. at 46 .

266. ClaRK, supra note 109 , at 40.

267. Id. at 41.

268. Id.

269. JONES, supra note 1, at 47.

270. Id. at 48-49.

271. See, e.g., McKenna, supra note 21, at A26. "A loan repayment rate of 94 to 98 percent shows that people previously labeled as not credit-worthy are indeed bankable. They make up in industry and ingenuity what they lack in capital." Id.

272. See, e.g., Eaton, supra note 139, at B1. "Because almost all the money gets repaid, it can be reused, making microcredit programs very cost-effective, proponents say. Some programs even make enough money from their lending to cover their costs." Id.

273. EDGCOMB, supra note 77, at 59.

274. MCLenighan, supra note 42, at 9.

275. EDGCOMB, supra note 77, at 3 . 
cost-to-loan ratio: "Instead of investing so much effort and time into microenterprise programs, why don't we just hire a helicopter, fly over the target neighborhoods, and throw the money out of the window?"276 Of course, as related above, there is more to microenterprise than merely banking, and the anecdote ends happily: "seeing firsthand the broad range of impact that the microenterprise program had on individuals, especially in developing 'human capital' (including self-esteem, confidence, and the drive to obtain financial self-sufficiency) this same board member became an enthusiastic convert ... "277 A collateral effect of the high transactional costs involved in handling such loans is the difficulty in turning a profit without charging high interest rates. ${ }^{278}$

Despite this persistent enthusiasm, major challenges remain. Perhaps the three greatest challenges are the need for health care coverage for microentrepreneurs and their families, a financial cushion, and ongoing technical assistance. ${ }^{279}$ The lack of health care is especially poignant, as the sickness of an entrepreneur or a close relative can destroy an otherwise successful microenterprise: "[m]y sister on the first floor, she didn't have anyone else to help her ... she's in a wheelchair and is a dialysis patient. I just couldn't walk away from her. ${ }^{280}$ Perhaps these problems can be remedied by variations of the Bangladeshi adaptations of Grameen II outlined previously. "Generally, all programs are urged to offer clients access to credit through innovative bank and other linkages ...."281 The question becomes how much programs are willing to experiment and how much risk they are willing to assume. The next section explores concepts of Islamic banking law, the implementation of which can allow microlenders the opportunity to offer loans at lower interest rates and afford microentrepreneurs the ability to set aside the difference for health coverage or a rainy day fund.

\section{MICROCREDIT AND EQUITY LENDING.}

\section{A. Applications of Equity Lending Without Interest ${ }^{282}$}

The past twenty years have seen tremendous growth in Islamic

276. JONES, supra note 1 , at 13.

277. Id.

278. Hurt, supra note 76 , at 3-4.

279. CLARK, supra note 109 , at viii.

280. Id. at 25.

281. JONES, supra note 1 , at 8 .

282. See MuHAMmad Umer Chapra \& Rashid Rahman, TOWARdS a Just MONETARY SYSTEM 68 (1986) (noting that equity lending "not only distribute[s] equitably the return on total investment between the financier and the entrepreneur, but also transfer[s] a fair share of the risk of the risks of investment to the financier instead of putting the whole burden on the entrepreneur."). 
banking. ${ }^{283}$ Estimated worldwide deposits surpass $\$ 80$ billion in more than forty-five countries. ${ }^{284}$ By 1999 , the annual turnover was estimated at $\$ 70$ billion, and it was projected to surpass $\$ 100$ billion by $2000 .^{285}$ Paradoxically to the Western mind, these results have been achieved in a system that prohibits the charging and payment of interest. ${ }^{286}$ The Koran prohibits the practice of usury. ${ }^{287}$ Whether this ban covers only the charging of exorbitant interest or the charging of any interest whatsoever is the subject of scholarly debate. ${ }^{288}$ The rejection of interest centers on the perceived injustice of a borrower compelled to return more than he borrowed. ${ }^{289}$ The use of paper money, credit cards, and checks is also considered to be a form of usury as it contributes to inflation. ${ }^{290}$ Wealth is accumulated through investment and mutually agreed upon ventures. $^{291}$ Islamic law imposes two requirements on such enterprises: (1) each investor has an equal voice in decision-making, regardless of amount invested; and (2) the investment need not be monetary, but can come in the form of time, skill, or effort. ${ }^{292}$

These banking principles work best on a smaller scale. To date, no interest-free national economies have been established, ${ }^{293}$ nor has anyone, "at the very least, opened a successful zero-interest investment fund in an [industrialized] country which could be taken as a model by believers and unbelievers alike."294 Proponents claim that not only are such large-scale

283. Rahul Dhumale \& Amela Sapcanin, An Application of Islamic Banking Principles to Microfinance, at 9, U.N. Doc. 23073 (Dec. 1999) [hereinafter Islamic Banking].

284. Id.

285. It is unclear what affect the events of September 11, 2001 and the invasions of Afghanistan and Iraq have had on international Islamic banking. See Hurt, supra note 76, at 3-4 (noting in passing that microfinance is "an idea that is taking on renewed popularity in the wake of Sept. 11, 2001, and the wars in Afghanistan and Iraq"). Cf. Impact of Iraq War on Sovereign Credit Ratings in Arab Region, Gulf NEws, (Jan. 28, 2006) at http://www.gulfnews.com/Articles/print.asp?ArticleID=111371 (reviewing changes in the Standard \& Poor's rating for various nations in the Middle East in the wake of the Iraq War).

286. Islamic Banking, supra note 283, at 1.

287. See THE KoRAN 270 (trans. J.M. Rodwell) (1994). "Whatever ye put out at usury to increase it with the substance of others shall have no increase from God: but whatever ye shall give in alms, as seeking the face of alms, shall be doubled to you." Id. "O believers! Fear God and abandon your remaining usury, if ye are indeed believers." Id. at 30. "O ye who believe! devour not usury, doubling it again and again and again! But fear God, that ye may prosper." Id.

288. Islamic Banking, supra note 283 , at 1 .

289. RICHARD DOUTHWATtE, SHORT CIRCUIT: STRENGTHENING LOCAL ECONOMIES FOR AN UNSTABLE WORLD, http://www.feasta.org/documents/shortcircuit/index.html?sc4/wsep.html (n.d.) (last visited Mar. 20, 2006) [hereinafter SHORT CIRCUIT].

290. Id.

291. Id.

292. Id.

293. Id. (citing MAHMUD AHMAD, TOWARDS INTEREST-Free BANKING (2000)). "[N]ot a single Muslim country ... is running its financial institutions without resorting to interest. The fact is that no one knows how to do it and when political pressure mounts, they can only resort to some kind of subterfuge." Id.

294. Id. 
ventures possible, but they would lead to greater economic stability. Under such a system, participants would technically be debt-free. ${ }^{295}$ During periods of economic decline, profit shares would decline equally for everyone, and no one would be left with onerous interest payments. ${ }^{296}$

Rather than charging and paying interest, traditional Islamic banking systems are based either on the sharing of profit and loss or the charging of a pre-arranged fee. ${ }^{297}$ Of the former group, the two most relevant for possible microcredit application are mudaraba, or trustee financing, and musharaka, or equity participation. ${ }^{298}$ Of the latter group, murabaha, or cost plus markup, is the most relevant. ${ }^{299}$ The main difference between the two categories is that for trustee financing and equity participation, the return is variable and is calculated at the end of the loan period, or for longer loans, at fixed periods. ${ }^{300}$ In none of these situations may a contract be negotiated to provide a fixed rate of return. ${ }^{301}$

\section{Mudaraba}

Under mudaraba, or trustee financing, as it shall be called for the remainder of this Note, each partner agrees to a fixed share of the profits based on a contractual agreement. ${ }^{302}$ Neither the gross nor the net returns may be predetermined. ${ }^{303}$ Losses must be shared equally by all partners. ${ }^{304}$ A modern application of trustee financing emends the traditional arrangement by allowing the ratio of return to be negotiated between the partners at the outset of the venture. $^{305}$ The risk of financial loss is assumed completely by the financial backer, usually a bank. ${ }^{306}$ Borrower liability is limited to the entrepreneur's lost time and effort, unless the bank can show negligence or malfeasance on the part of the borrower. ${ }^{307}$ Proponents of this system indicate that under such an

295. Id.

296. Id. In an American context, perhaps such lending practices might have led bankers during the Great Depression to commiserate with dustbowl farmers rather than foreclose their mortgages.

297. Shaikh Mahmud AHMAd, Man and Money: Towards an Alternative Basis of CREDIT 432 (2002).

298. Islamic Banking, supra note 283, at 3.

299. See, e.g., JONES, supra note 1, at 36 (noting that some U.S. microlenders protect themselves against borrower bankruptcy by retaining a security interest in borrowers' capital purchases).

300. Islamic Banking, supra note 283, at 5.

301. Id.

302. Instruments of Islamic Investments: Mudaraba, available at http://www.altawfeek.com/reslcll.htm (n.d.) (last visited Mar. 20, 2006) [hereinafter Instruments].

303. Islamic Banking, supra note 283, at 3.

304. Id. See also Instruments, supra note 302.

305. Islamic Banking, supra note 283, at 3.

306. Instruments, supra note 302.

307. Islamic Banking, supra note 283 , at 8. 
arrangement, with financial risk completely on the lender, banks would be more circumspect in their lending practices, thus eliminating the need to charge interest. $^{308}$

This does not sound like the kind of argument that would win over many converts in the banking industry, but it is applicable to microlending. Unlike Islamic banking, where there is an outright ban on interest regardless of amount, microlenders could assume part of the loan risk through trustee financing. In exchange for part of the profit of the microentrepreneur's business, the microlender can reduce the interest it charges to the microentrepreneur. As the microentrepreneur returns for further loans, the interest rate can be raised or lowered according to the health of their repayment history. The lower the risk of default, the more burden of risk the lender should be able to shoulder. ${ }^{309}$

The trustee financing model is not without its disadvantages. Chief among them is the uncertainty of profit and the subsequent difficulty of calculating share returns. ${ }^{310}$ Under this type of contract arrangement, the lender and borrower are partners. At first, the lender controls all the shares and is entitled to $100 \%$ of the profits. ${ }^{311}$ As each loan installment is repaid, the borrower buys control of shares, simultaneously increasing his share and decreasing the lender's share of the profits. ${ }^{312}$ This continues until the borrower controls $100 \%$ of the profits. At this point, the loan is paid in full. ${ }^{313}$

The repayment system is complex enough without taking market fluctuations into consideration. The situation is further complicated by the fact that, at least in a microcredit context, borrowers may not keep accurate and detailed records. ${ }^{314}$ Dealing with profit share payment under trustee financing might also pose a problem for people with no exposure to Islamic banking practices. In fact, "the acceptability of [this] model depends rather heavily on whether such an agreement is in accordance with Islamic banking principles."315 One might argue that, since an important component of microcredit is the training and support that accompanies it, borrowers can be trained to work effectively with bookkeeping for purposes of profit share calculation. ${ }^{316}$ This, however, leads to the question of where the microlender case workers will get their training. "The margin for error is considerable given that a single loan officer often manages 100-200 borrowers."317

308. SHORT CIRCUIT, supra note 289.

309. Cf. Grameen II, supra note 72 (discussing the "flexible loan" repayment program whereby lowered risk of default allows rescheduling of debt).

310. Islamic Banking, supra note 283, at 8.

311. See Appendix, tables 5 \& 6 .

312. Islamic Banking, supra note 283, at 8 .

313. Id.

314. Id. at 10.

315. Id.

316. ClaRK, supra note 109 , at 69-70.

317. Islamic Banking, supra note 283, at 10 . Since the current clientele of U.S. 


\section{Murabaha}

Under murabaha, or cost plus markup, the lender actually purchases the capital goods the borrower needs and would have otherwise borrowed money to purchase. ${ }^{318}$ The borrower repays the lender the price of the goods plus an additional fee to cover administrative costs. ${ }^{319}$ Cost plus markup is one of the most common forms of Islamic banking practice. ${ }^{320}$ It is used to obtain machinery, raw materials, and finished goods. ${ }^{321}$ Loan repayment under this system is easier to grasp and, subsequently, easier to predict. Something similar to cost plus markup is already practiced in the United States. As a means to protect against borrower bankruptcy, microlenders will sometimes take a security interest in goods purchased with the loan money. ${ }^{322}$ While this approximates a murabaha arrangement, it is technically different because there is no corresponding markup on the capital goods. ${ }^{323}$

Cost plus markup seems more conducive to Grameen banking, as well. A Yemeni microfinance program started in 1997 grew within two years to an active membership of 1,000 , with $\$ 150,000$ in loans outstanding and a turnaround of one week. ${ }^{324}$ The clients were "entrepreneurial poor in urban slum districts." 325 The program adopted the Grameen $\Pi$ innovations of loan insurance and increasingly larger loans. ${ }^{326}$ Unlike the Bangladeshi model, only thirty percent of the Yemeni participants were women. ${ }^{327}$

Because the markup is predetermined, this type of loan contract typically costs the borrower less. ${ }^{328}$ Of course, under a trustee financing arrangement, the borrower could stand to earn a greater absolute amount of money, but there is no guarantee. Also, some prefer the markup system because of its inherent transparency. ${ }^{329}$ In fact, it is easier to enforce because the lender owns the goods until the final installment is paid, ${ }^{330}$ in a sort of lending layaway. Trustee

microlenders is significantly lower than in places such as Bangladesh, this concern is not as great yet it remains valid. $I d$.

318. Id. at 10.

319. Id. at 11 .

320. Instruments of Islamic Investments: Murabaha Sale, available at http://www.altawfeek.com/res lclb.htm (n.d.) (last visited Mar. 20, 2006) [hereinafter Islamic Investments].

321. Id.

322. JONES, supra note 1 , at 36 .

323. Id. (not mentioning any surcharge made to the borrower for the lender's security interest). It would seem that, rather than turn a profit, a U.S. microlender would experience a loss in depreciation were it to claim its security share. See id. This loss could be aggravated by an inability to resell the item and subsequent storage charges, at which point such an arrangement may prove inefficient. See id.

324. Islamic Banking, supra note 283, at 11.

325. Id.

326. Id.

327. Id.

328. Id. at 12.

329. Id.

330. Id. 
financing is more difficult to police. Due to its complexity and unpredictability, honest error, negligence, or malfeasance may go undetected. ${ }^{331}$ However, it retains the advantage of all parties sharing in the profits, and in some respects, the losses, equally. ${ }^{332}$ These tradeoffs are important to keep in mind. Although writing about Islamic banking in particular, Dhumale and Sapcanin make a point applicable to all forms of financing when they write that program must account "for the ... risks of a particular methodology not only to the program but also to borrowers." 333

\section{A. Application of Equity Lending in the United States}

To a very limited extent, equity microlending already exists in the United States. ${ }^{334}$ One example is the Philadelphia Development Partnership, which offers zero-interest loans to Muslim microentrepreneurs based on tenets of Islamic banking. ${ }^{335}$ It is important to keep in mind that even though hypothetical microloans can be disbursed using Islamic banking theory, loans to non-Muslims need not be zero-interest. In exchange for a limited share of the microentrepreneur's profits, the lender could offer a reduced interest rate that would both ease the burden of repayment and give the lender a more vested interest in the entrepreneur's success. Any lender profit realized from the transaction could be funneled into technical assistance generally, or into specific health or rainy-day accounts for the particular entrepreneur. ${ }^{336}$

\section{B. Challenges to Wider Adoption of Equity Microlending in the United States}

The three main challenges to the wider adoption of equity microlending in the United States are anti-Islamic sentiment, ${ }^{337}$ the complexity of the equity microlending, ${ }^{338}$ and, in a broader sense, the negative scrutiny placed on those who even this "softer" version of microenterprise cannot help. ${ }^{339}$ The first obstacle seems hardly worth mentioning but, considering the current wars in Afghanistan and Iraq, the topic should be addressed, however briefly. Microlenders, one would hope, are socially conscious humanitarians who place the welfare of their clients above any prejudices they may harbor. As for the

331. Id. at 4.

332. Id. at 3.

333. Id.

334. JONES, supra note 1 , at 66 .

335. Id.

336. See, e.g., Clark, supra note 109 , at 69 . The supposition that profits may be used for these collateral goals, of course, assumes that a microlender would have sufficient funding or successful borrowers to both offset the losses of failed microenterprises and to absorb the costs of a health care plan.

337. Ubaid, supra note 17.

338. See generally lslamic Banking, supra note 283.

339. See, e.g., Jones, supra note 170. 
microentrepreneurs, their main concern would most likely be successfully starting their businesses and rising from poverty. ${ }^{340}$

The second challenge, however, is much more daunting. As shown above, Islamic banking models are highly complex and counterintuitive to people who are accustomed to operating under interest-driven finance. In fact, the charts in the appendix depicting the distribution of borrower and lender profits are artificially simplified with a fixed periodic profit of $\$ 1,000$ to demonstrate the basic mechanism of profit sharing. ${ }^{341}$ However, it should be kept in mind that microcredit is much more complicated and labor intensive than conventional banking; "groups must think seriously about commitment and be prepared for the long haul because microenterprises are expensive to operate and involve a large time commitment for practitioners." ${ }^{342}$ In her legal guide to microenterprise, Jones details a number of planning issues that practitioners have identified as important to consider. ${ }^{343}$ One such recommendation is a call for greater transparency in reporting:

If a bank services the microloans, it is important for the bank and the microenterprise program staff to maintain close communication. Negotiate with the bank for timely reports on borrowers' payments. These reports should be weekly or biweekly; monthly reports are insufficient because they allow for extended unsupervised periods of default. The microenterprise programs need to know immediately if borrowers are having trouble making loan payments. ${ }^{344}$

For the program experimenting with equity microlending, the suggestion to maintain transparency becomes paramount. Not only must borrowers be aware of non-standard financial arrangements, the financial institutions that back the loans must be even more aware. In this regard, equity microlending may be a viable option for only those microlenders who maintain complete control of their financial resources. ${ }^{345}$

Finally, if equity lending has the positive benefit of opening microenterprise possibilities for a wider array of poor entrepreneurs, it might also have the unintended effect of bringing increased negative scrutiny to those persons who are unable to participate in microenterprise projects. Numerous factors, such as environmental, social, and psychological, have a bearing on an individual's ability to rise from poverty. ${ }^{346}$ "There are as many routes out of

340. See, e.g., WSEP, supra 186.

341. See Appendix, tables 5 \& 6; Islamic Banking, supra note 283, at 9.

342. JONES, supra note 1 , at 39-40.

343. Id. at 42.

344. Id.

345. See, e.g., Eaton, supra note 139, at B1 ("Accion New York ... has had the most trouble with its loans to taxi and livery drivers because they move around so much ....").

346. Clark, supra note 109 , at 15. 
poverty as there are into poverty." ${ }^{347}$ In her address before the microcredit summit, Hillary Clinton observed that "[i]t is the individual human being willing to work hard who will be given the opportunity if that person takes responsibility to seek and find a better life for themselves [sic]."348 The language of choice and responsibility of this quotation su'ggests that a person unable to work hard might be viewed as unwilling to work hard, and a moral stigma attaches to those who cannot benefit from microcredit. ${ }^{349}$ In considering adaptations and improvements to the application of microcredit in the United States, it is important to keep in mind the admonition that is often repeated in the international context: "The United States and other donor nations should not place unrealistic conditions on their support for those who work micromiracles. Nor should they use this program as a substitute for other more basic ways of helping the poorest of the poor." 350

\section{CONCLUSION}

Since its creation in the 1970 s, microcredit has demonstrated both its simplicity and effectiveness. Banking on a person's potential rather than her credit or collateral has helped countless families worldwide to break free of poverty. Microcredit has also been successful in the United States; however, the transfer from the developing nation and agrarian village society to a highly regulated urban America has not been as smooth as microcredit proponents had originally envisaged. Still, the fundamental concepts of microcredit have proven highly adaptable in the new context. Central to microcredit's success in the United States is the desire of microlenders and microentrepreneurs to see the system succeed. It is a moral force that transcends simple banking.

The goal of this Note is to suggest a further adaptation of the Grameen microcredit model. By incorporating elements of Islamic banking, specifically, techniques which would allow microlender to move away from dependence on high interest rates, the lenders could either offer lower rates to microentrepreneurs to cushion their introduction to self-employment or they could funnel the money into accounts which could provide health insurance or emergency funds for their borrowers.

The problems associated with such a project might make it impractical on a wide scale. The largest obstacle is the complexity and alien nature of interestfree banking. It is an experiment for only the most dedicated and dauntless

347. Id. (quoting Robert E. Friedman, Microenterprise as an Asset Building Strategy Among the Poor, Presentation at a Ford Foundation Conference at New York University (December 10-12, 1998)).

348. Clinton, supra note 112.

349. For example, the popular title of Pub. L. No. 104-193, i.e., Personal Responsibility \& Work Opportunity Reconciliation Act of 1996, suggests the morally stigmatic dimension of individual welfare programs.

350. Microcredit's Limits, supra note 4, at 8. 
microlenders to undertake. However, it does provide an opportunity for microlenders to expand and shore up their clientele in certain key areas.

Finally, it is important to bear in mind that for all its potential, microcredit is not a silver bullet to end poverty in the United States. That being said, it should also be remembered that microcredit is an option for only a fraction of the nation's poor people. Those who cannot be helped by microcredit must not be blamed for the limitations of the program. 
Appendix

Table 1. Household Assets of Low-Income Microentrepreneurs

Household Assets of Low-Income Microentrepreneurs

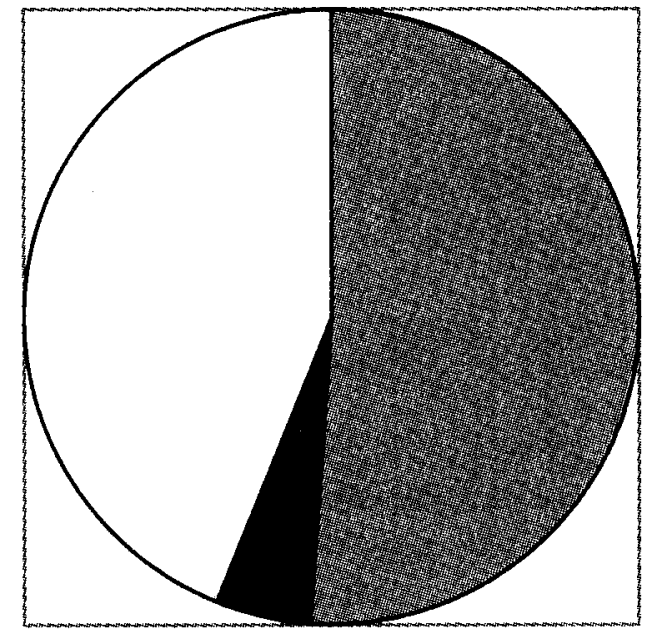

\begin{tabular}{|l}
$0-\$ 5,000$ \\
$\square 5,001-10,000$ \\
$\square>\$ 10,000$
\end{tabular}

Source: PEgGY ClaRK ET AL., MicRoENTERPRISE AND tHE POOR: FINDINGS FROM THE SELF-EMPLOYMENT LEARNING PROJECT, FIVE YEAR STUDY OF MICROENTREPRENEURS 21 (1999). 
Table 2. Comparison of SELP Poor Respondents to the Poor in the U.S. by Key Characteristic: Household Composition and Government Benefits Receipt

Comparison of SELP Poor Respondents to the Poor in the U.S. by Key Characteristics: HOUSEHOLD COMPOSITION AND GOVERNMENT BENEFITS RECEIPT

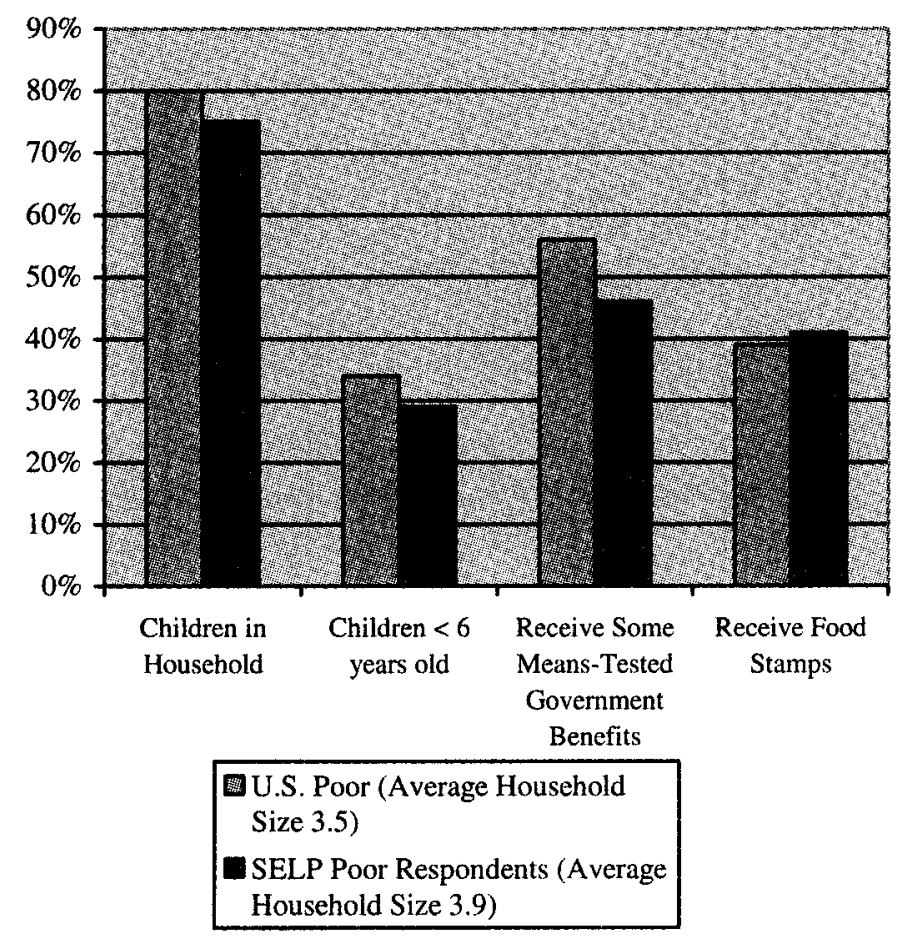

Source: PEgGY Clark ET AL., MicroenterPRISE AND THE POOR: Findings FROM THE SELF-EMPLOYMENT LEARNING PROJECT, FIVE YEAR STUDY OF MICROENTREPRENEURS 14 (1999). 
Table 3. Comparison of SELP Poor Respondents to the Poor in the U.S. by Key Characteristic: Education Level Attained

Comparison of SELP Poor Respondents to the Poor in the U.S. by Key Characteristics: EDUCATION LEVEL ATTAINED

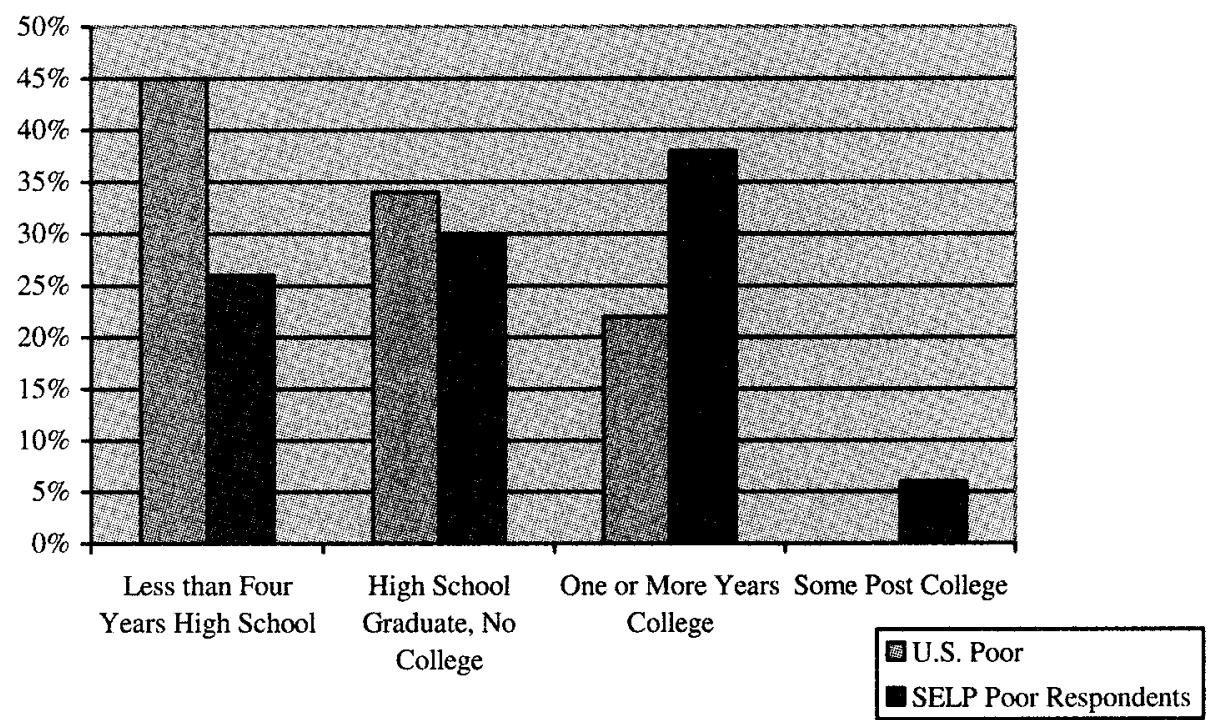

Source: Peggy Clark et AL., MiCROENTERPRISE AND THE POOR: FINDINGS FROM THE SELF-EMPLOYMENT LEARNING PROJECT, FIVE YEAR STUdy OF MICROENTREPRENEURS 14 (1999). 
Table 4. Comparative Change in Governmental Assistance to Poor Microentrepreneurs

Comparative Change in Governmental Assistance to Poor Microentrepreneurs

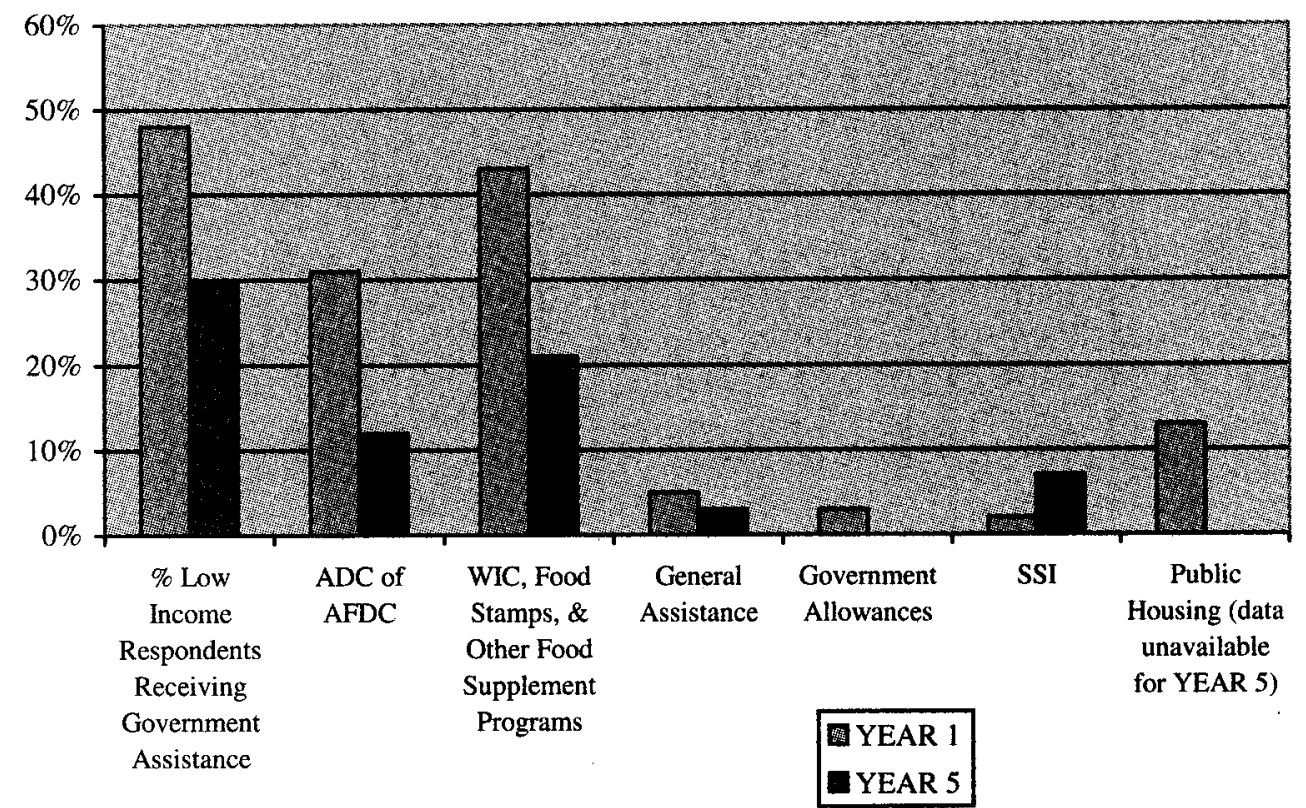

Source: Peggy Clark et al., Microenterprise and the Poor: Findings from the Self-Employment Learning Project, Five Year Study of Microentrepreneurs 37 (1999). 
Table 5. Lender and Entrepreneur Profits under a Mudaraba Model

(Full profits go to entrepreneur at the twenty-first week).

(Profit artificially fixed at $\$ 1,000$ per week for sake of example).

\begin{tabular}{|c|c|c|c|}
\hline Week & Profit to be shared & Lender Income & Entrepreneur Income \\
\hline 1 & $20 / 20 \times \$ 1,000$ & $\begin{array}{l}\$ 1,000 \times 10 \%= \\
\$ 100\end{array}$ & $\$ 1,000 \times 90 \%=\$ 900$ \\
\hline 2 & $19 / 20 \times \$ 1,000$ & $\$ 950 \times 10 \%=\$ 95$ & $\$ 1,000 \times 90 \%=\$ 905$ \\
\hline 3 & $18 / 20 \times \$ 1,000$ & $\$ 900 \times 10 \%=\$ 90$ & $\$ 1,000 \times 90 \%=\$ 910$ \\
\hline 4 & $17 / 20 \times \$ 1,000$ & $\$ 850 \times 10 \%=\$ 85$ & $\$ 1,000 \times 90 \%=\$ 915$ \\
\hline 5 & $16 / 20 \times \$ 1,000$ & $\$ 800 \times 10 \%=\$ 80$ & $\$ 1,000 \times 90 \%=\$ 920$ \\
\hline 6 & $15 / 20 \times \$ 1,000$ & $\$ 750 \times 10 \%=\$ 75$ & $\$ 1,000 \times 90 \%=\$ 925$ \\
\hline 7 & $14 / 20 \times \$ 1,000$ & $\$ 700 \times 10 \%=\$ 70$ & $\$ 1,000 \times 90 \%=\$ 930$ \\
\hline 8 & $13 / 20 \times \$ 1,000$ & $\$ 650 \times 10 \%=\$ 65$ & $\$ 1,000 \times 90 \%=\$ 935$ \\
\hline 9 & $12 / 20 \times \$ 1,000$ & $\$ 600 \times 10 \%=\$ 60$ & $\$ 1,000 \times 90 \%=\$ 940$ \\
\hline 10 & $11 / 20 \times \$ 1,000$ & $\$ 550 \times 10 \%=\$ 55$ & $\$ 1,000 \times 90 \%=\$ 945$ \\
\hline 11 & $10 / 20 \times \$ 1,000$ & $\$ 500 \times 10 \%=\$ 50$ & $\$ 1,000 \times 90 \%=\$ 950$ \\
\hline 12 & $9 / 20 \times \$ 1,000$ & $\$ 450 \times 10 \%=\$ 45$ & $\$ 1,000 \times 90 \%=\$ 955$ \\
\hline 13 & $8 / 20 \times \$ 1,000$ & $\$ 400 \times 10 \%=\$ 40$ & $\$ 1,000 \times 90 \%=\$ 960$ \\
\hline 14 & $7 / 20 \times \$ 1,000$ & $\$ 350 \times 10 \%=\$ 35$ & $\$ 1,000 \times 90 \%=\$ 965$ \\
\hline 15 & $6 / 20 \times \$ 1,000$ & $\$ 300 \times 10 \%=\$ 30$ & $\$ 1,000 \times 90 \%=\$ 970$ \\
\hline 16 & $5 / 20 \times \$ 1,000$ & $\$ 250 \times 10 \%=\$ 25$ & $\$ 1,000 \times 90 \%=\$ 975$ \\
\hline 17 & $4 / 20 \times \$ 1,000$ & $\$ 200 \times 10 \%=\$ 20$ & $\$ 1,000 \times 90 \%=\$ 980$ \\
\hline 18 & $3 / 20 \times \$ 1,000$ & $\$ 150 \times 10 \%=\$ 15$ & $\$ 1,000 \times 90 \%=\$ 985$ \\
\hline 19 & $2 / 20 \times \$ 1,000$ & $\$ 100 \times 10 \%=\$ 10$ & $\$ 1,000 \times 90 \%=\$ 990$ \\
\hline 20 & $1 / 20 \times \$ 1,000$ & $\$ 50 \times 10 \%=\$ 5$ & $\$ 1,000 \times 90 \%=\$ 995$ \\
\hline Total & & $\$ 1,050$ & $\$ 18,950$ \\
\hline
\end{tabular}

Source: Rahul Dhumale \& Amela Sapcanin, An Application of Islamic Banking Principles to Microfinance at 9, U.N. Doc. 23073 (Dec. 1999). 
Table 6. Lender and Entrepreneur Profit Distribution under a Mudaraba Model

Lender/Entrepreneur Profit Distribution Under Mudaraba Model

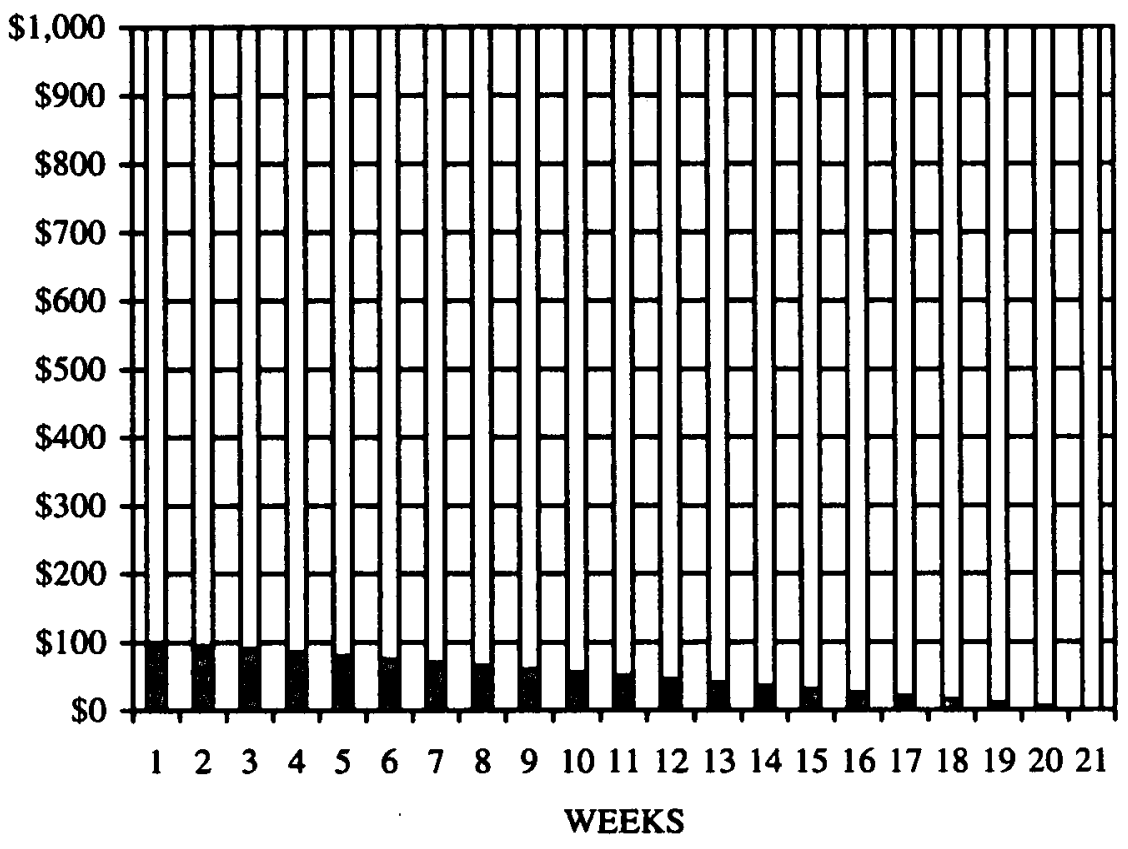

DEntrepreneur Profit

Lender Profit

Source: Data taken from Table 5. 
